\title{
MICROBIAL DIVERSITY AND DENSITY IN THE CORAL REEF ENVIRONMENT OF THE GULF OF MANNAR
}

\author{
BALASUBRAMANIAN, R. ${ }^{1} *-$ KANNAN, L. $^{2}$ \\ ${ }^{1}$ People's Action for Development (PAD), \\ 2/29 Sebastian Koil Street, Vembar - 628 906, Thoothukudi - Dist., India \\ (phone: + 919443426469$)$ \\ ${ }^{2}$ Centre of Advance study in Marine Biology \\ Annamalai University, Parangipettai-608 502. \\ *Corresponding author \\ e-mail: coralbalu@gmail.com \\ (Received 20 $0^{\text {th }}$ October 2009; accepted $10^{\text {th }}$ February 2012)
}

\begin{abstract}
Microbes are important in the coral reef environment in the recycling of nutrients and as a source of food to a variety of animal species. They also have an important trophic role to play in the reef environment, goverened by different physico-chemical and biotic factors. The present study has revealed the presence of more THB (total heterotropic bacteria) population density in water (5.2 to $22.5 \times 10^{5}$ $\mathrm{CFUml}^{-1}$ ) and in the sediments ( 7 to $24.2 \times 10^{7} \mathrm{CFUg}^{-1}$ ) than in the surrounding coastal environments. A total of 24 species of planktonic cyanobacteria and 11 species of benthic cyanobacteria were recorded. Among them, Phormidium tenue was the most dominant species and the families Oscillatoriaceae and Chroococcaceae were predominant in the present study. A total of 35 species of fungi belonging to 20 genera representing the families Labyrinthulomycetes, Oomycetes, Zygomycetes and Deuteromycetes were isolated. Among them, the deuteromycetous fungi formed the bulk of the mycoflora of all the samples at both stations.
\end{abstract}

Keywords: Coral reef microbes, Gulf of Mannar, Bacteria, Cyanobacteria , Fungi THB

\section{Introduction}

Under normal conditions, corals co-exist with the microorganisms that are abundant in the marine environment. However, when corals are stressed by high temperatures, increased nutrient concentrations or sedimentation, these microbes may cause disease to them (Baird, 2000). Rising water temperatures or reduction in water quality will reduce the resistance of corals and increase the virulence of the microbes.

Much is known about the role of microbes in terrestrial and fresh water ecosystems when compared to the marine environment. Marine microbes play a major role in the biogeochemical cycles, regulating the distribution of nutrients throughout the ocean (Hoppe and Gocke, 1993), in addition they are important in the maintenance of the community (Hoppe et al., 1988). In fact, the microbial population in the reef system is responsible for the decomposition of organic material reaching the coral reef environment, thus supplying the needed nutrients. They also serve as a direct source of food for a variety of reef organisms. At the same time it should be noted that the microbes viz. bacteria, cyanobacteria and fungi can affect the corals by causing diseases which may lead even to devastation.

Heterotrophic bacteria have long been recognized as important agents of carbon and nitrogen cycling in the coral reefs (Ducklow, 1990) and bacterial respiration is an important component of coral community metabolism (Sargeant and Austin, 1949). 
Of the different microbes, cyanobacteria, which are the oxygen evolving photosynthetic prokaryotes, inhabit various types of marine environs. They play a vital role in the carbon cycle of oligotrophic waters (Hagstrom et al., 1988).

Marine fungi are the potential source for a variety of extra cellular enzymes (Rohrmann and Molitoris, 1992) and calcium carbonate substrata such as shells of dead molluscs, coral skeletons, as well as coralline algae are the common habitat of these fungi. They decompose the organic matter into nutrients thus playing an important role in the cycling of nutrients.

Though there have been some attempts to study the bacteria and fungi of the coral reef environment of India, a holistic approach to assess the microbial (bacteria, cyanobacteria and fungi) diversity and density in the water and sediments of the coral reef environment of the Gulf of Mannar is lacking. Further, this assessment is essential because these microbes present in the ambient environment may turn into pathogens, when coral species are stressed. Having this in mind, the present study was carried out at two stations viz. Manoli island (Station 1) and Krusadai island (Station 2) in the Gulf of Mannar.

\section{Materials and methods}

The Gulf of Mannar is situated on the southeast coast of India. In the Gulf area, there is an arc of 21 islands starting from the northern most Rameswaram island to Tuticorin ( $8^{0} 46^{\prime}$ and $9^{0} 14^{\prime} \mathrm{N}$ Lat; $78^{0} 9^{\prime}$ and $79^{\circ} 14^{\prime}$ E Long.) forming the 'archipelago', called 'Mannar Barriers'. Among these islands only two were selected for the present study, station 1 Manoli island and station 2 Kurusadai island.(Fig. 1)

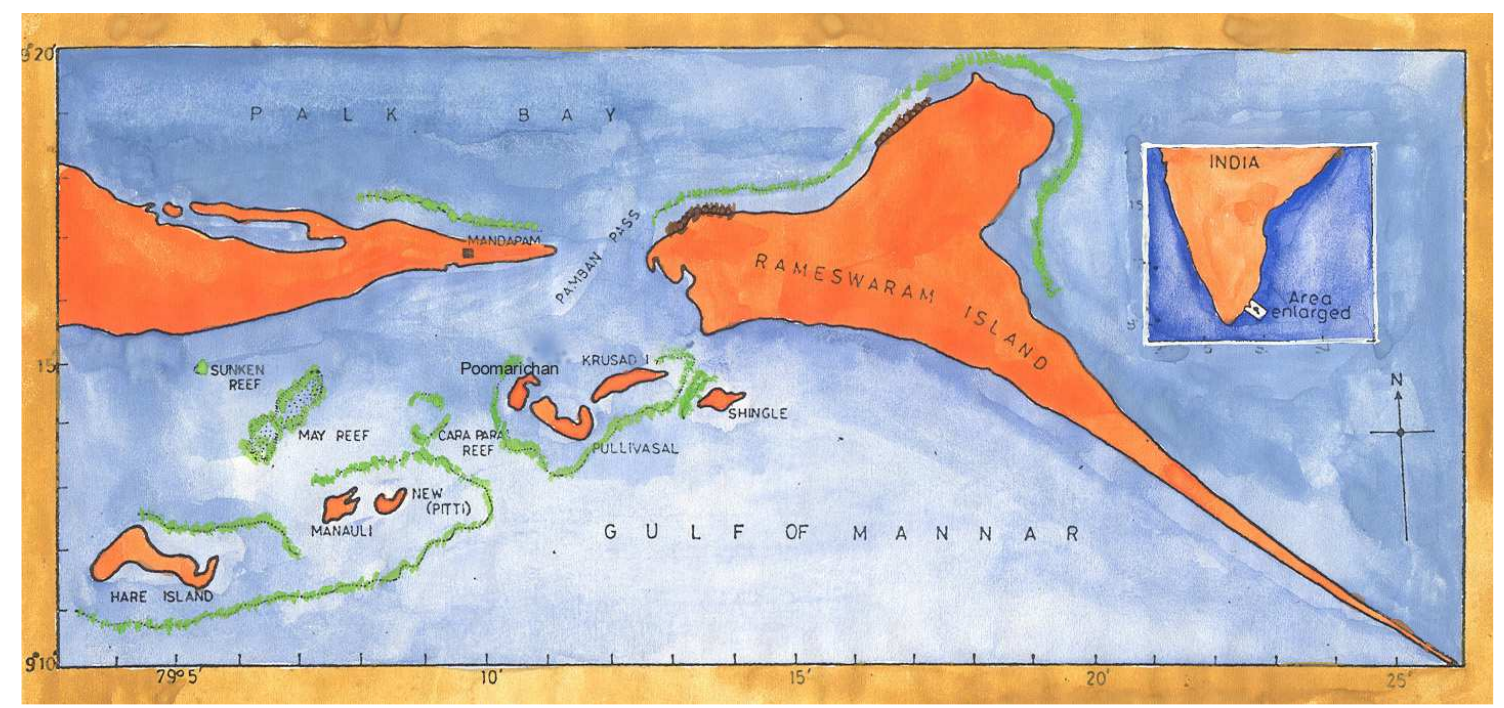

Figure 1. Study area

For microbiological assessment, water and sediment samples were collected from both the stations. 


\section{Bacteria}

\section{Isolation of total heterotropic bacteria (THB)}

Total heterotrophic bacteria were isolated from water and sediments, adopting the serial dilution plating technique using Zobell Marine Agar 2216 medium (Himedia Chemicals Pvt. Ltd., Mumbai). Identification of the pure cultures up to generic level was done with the schemes of Buchanan and Gibbons (1975), Krieg (1984) and Sneath (1986).

\section{Cyanobacteria}

\section{Planktonic cyanobacteria}

The planktonic cyanobacteria were collected using a plankton net made of bolting silk cloth of no. 25 with pore size of approximately $64 \mu \mathrm{m}$. The net was towed for about 10 minutes in the surface water and the samples were collected. The filtered plankton samples were transferred to wide mouthed polythene bottles and preserved in $4 \%$ formaldehyde and then analyzed under a light microscope.

\section{Benthic cyanobacteria}

Benthic cyanobacteria were collected from the intertidal cyanobacterial mats. The mats were removed from the substratum and suspended in $50 \mathrm{ml}$ of filtered water taken from the collection site and shaken gently to free the algae from the sand particles. The particles were allowed to settle for few minutes and the supernatant consisting of the benthic cyanobacteria were retained in the suspension. The samples were then analyzed after adding a few drops of $4 \%$ formaldehyde and Lugol's solution. Identification of species was carried out using the taxonomic publications of Desikachary (1959), Hum and Wicks (1980) and Anand (1989).

\section{Fungi}

For mycological analysis, the method of Prabhu et al., (1991) was followed. Standard pour plate technique was used to isolate and enumerate fungi, by making suitable dilutions of water and sediment samples. All the isolated colonies were identified up to species level referring to the works of Booth (1971), Ainsworth et al., (1973a,b), Ellis (1976) and Kohlmeyer and Kohlmeyer (1979).

Multiple regression analysis was done in order to determine the influence of the physico-chemical variables on the populations of THB, cyanobacteria and fungi. Summary of the multiple regression analysis is given station-wise in Tables 4 and 5 with regression equation. THB, cyanobacterial and fungal populations were considered as dependent variables and other parameters namely wind speed, rainfall, air temperature, surface water temperature, $\mathrm{pH}$, salinity, dissolved oxygen, particulate organic carbon, total phosphorus, inorganic phosphate, total nitrogen, nitrate, nitrite, silicate, calcium and magnesium were considered as independent variables. 


\section{Results}

\section{Total Heterotrophic Bacteria (THB)}

Among the bacterial strains isolated from the water and sediments at both the stations, a total of 245 strains were randomly sub-cultured and identified to generic level. Totally nine genera viz. Pseudomonas, Vibrio, Aeromonas, Flavobacterium, Enterobacter, Bacillus, Micrococcus, Arthrobacter and Corynebacterium were identified.

In general, gram negative bacteria showed a higher proportion $(59.13 \%)$ than the gram positive bacteria $(40.87 \%)$. When compared to station 1, station 2 recorded more gram negative genera.

THB population density in water varied from 5.2 to $22.5 \times 10^{5} \mathrm{CFU} \mathrm{ml}^{-1}$ at both the stations (Fig. 2). At both the stations, the minimum was recorded during the premonsoon and the maximum was recorded during the monsoon seasons.

Population density of THB in the sediments varied from 7 to $24.2 \times 10^{7} \mathrm{CFU} \mathrm{g}^{-1}$ at both the stations (Fig. 3). The same trend was recorded as in the case of water.

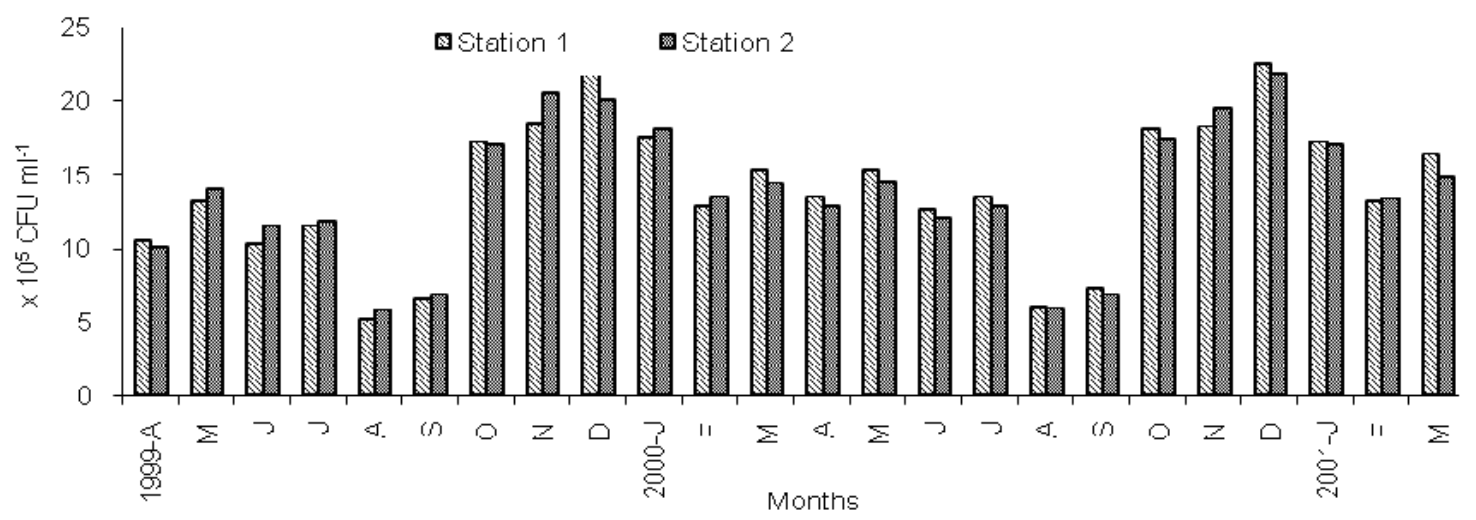

Figure 2. THB population density recorded in water at stations 1 and 2

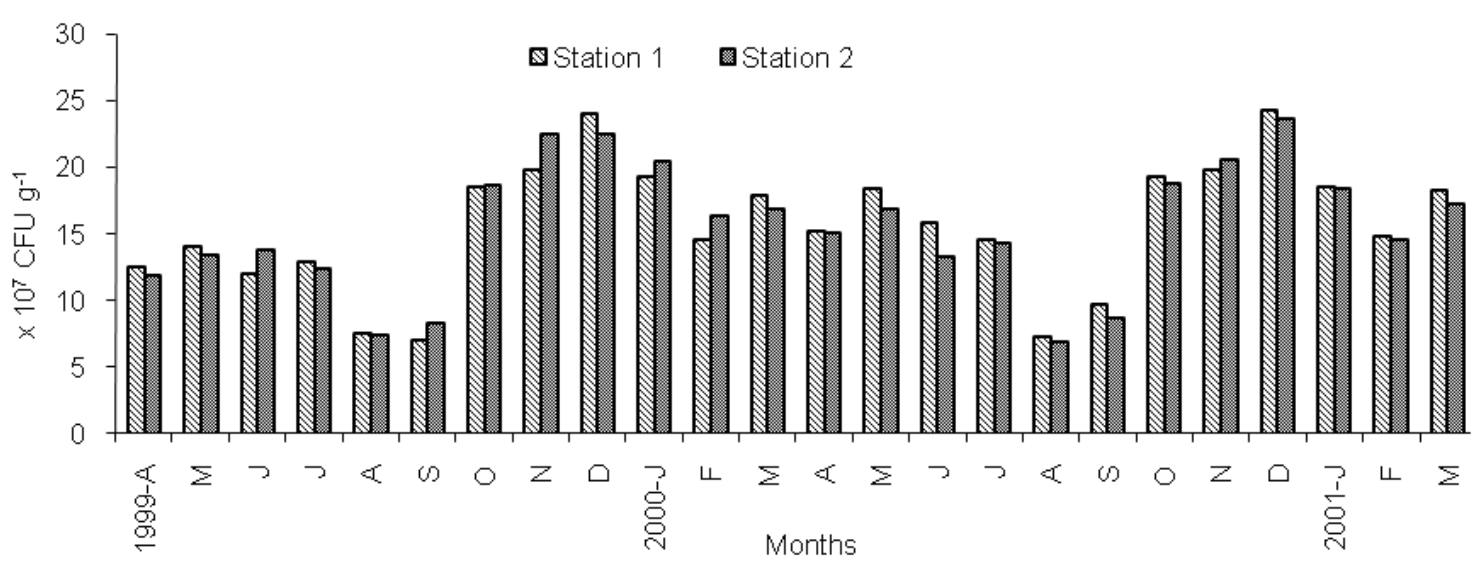

Figure 3. THB population denstity recorded in water at stations 1 and 2 


\section{Cyanobacteria}

Among the planktonic cyanobacteria, station1 recorded a total of 24 species belonging to 15 genera and 5 families while station 2 recorded a total of 22 species belonging to 15 genera and 5 families (Table 1).

Table 1. List of planktonic cyanobacteria recorded from stations 1 and 2

\begin{tabular}{|c|c|c|c|}
\hline S. No. & Species & Station 1 & Station 2 \\
\hline & Chroococcaceae & & \\
\hline 1. & Microcystis sp. & + & + \\
\hline 2. & Chroococcus turgidus & + & + \\
\hline 3. & Gloeocapsa sp. & + & + \\
\hline 4. & Aphanocapsa montana & + & + \\
\hline 5. & Aphanothece clathrata & + & + \\
\hline 6. & Synechocystis salina & + & + \\
\hline 7. & S. pevalekii & + & - \\
\hline \multirow[t]{2}{*}{8.} & S. aquatilis & + & - \\
\hline & Oscillatoriaceae & & \\
\hline 9. & Spirulina subsalsa & + & + \\
\hline 10. & Oscillatoria nigroviridis & + & + \\
\hline 11. & O. salina & + & + \\
\hline 12. & O. tenuis & + & + \\
\hline 13. & Oscillatoria sp. & & \\
\hline 14. & Trichodesmium erythraeum & + & + \\
\hline 15. & Phormidium fragile & + & + \\
\hline 16. & P. tenue & + & + \\
\hline 17. & P. ambiguum & + & + \\
\hline 18 & Phormidium sp. & + & + \\
\hline \multirow[t]{2}{*}{19.} & Lyngbya sp. & + & + \\
\hline & Nostocaceae & & \\
\hline 20. & Nostoc sp. & + & + \\
\hline \multirow[t]{2}{*}{21.} & Anabaena sp. & + & + \\
\hline & Scytonemataceae & & \\
\hline 22. & Plectonema terebrans & + & + \\
\hline \multirow[t]{2}{*}{23.} & Plectonema sp. & + & + \\
\hline & Rivulariaceae & & \\
\hline 24. & Calothrix sp. & + & + \\
\hline
\end{tabular}

In the case of benthic forms, a total of 11 species belonging to 8 genera and 4 families were recorded at both the stations (Table 2). Oscillatoria and Phormidium were found to be the dominant genera. 
Table 2. List of benthic cyanobacteria recorded from stations 1 and station 2.

\begin{tabular}{l|l|l|l}
\hline S. No. & Species & Station1 & Station 2 \\
\hline & Chroococcaceae & \multicolumn{2}{|l}{} \\
\hline 1. & Chroococcus minutus & + & + \\
\hline 2. & C. minor & + & + \\
\hline 3. & Gloeocapsa sp. & + & + \\
\hline 4. & Aphanocapsa montana & + & + \\
\hline & Oscillatoriaceae & \multicolumn{2}{|l}{} \\
\hline 5. & Oscillatoria sp. & + & + \\
\hline 6. & Phormidium sp. & + & + \\
\hline 7. & P. fragile & + & + \\
\hline 8. & P. tenue & + & + \\
\hline 9. & Lyngbya sp. & + & + \\
\hline 10. & Nostocaceae & \multicolumn{2}{|l}{} \\
\hline & Anabaena sp. & + & + \\
\hline 11. & Calothrix sp. & + & + \\
\hline
\end{tabular}

+ denotes Presence

- denotes absence

\section{Planktonic cyanobacteria}

Population density of cyanobacteria in water varied from 22 to 190 individuals/l at both stations (Fig. 4). At Station 1, the minimum and the maximum was recorded during the premonsoon and summer season respectively. At Station 2, the minimum was recorded during the premonsoon season and the maximum was recorded during the postmonsoon season.

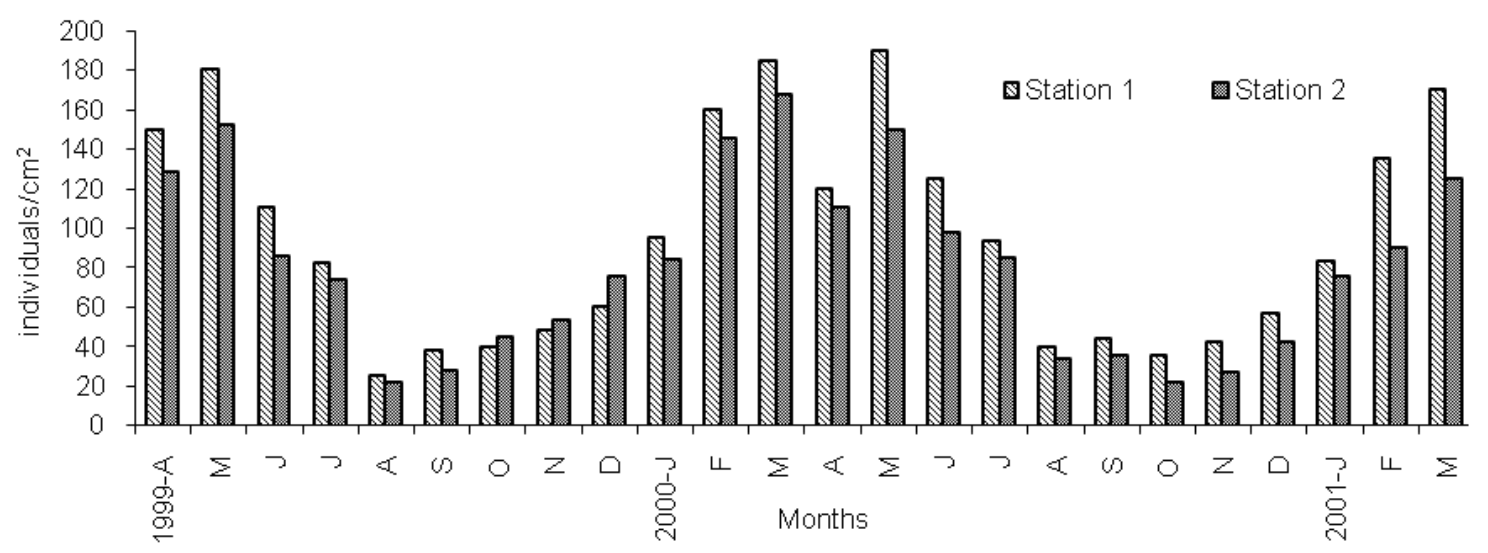

Figure 4. Population density of planktonic cyanobacteria recorded at stations 1 and 2 


\section{Benthic cyanobacteria}

Population density of cyanobacteria in sediments varied from 12 to 40 individuals $/ \mathrm{cm}^{2}$ (Fig. 5). At station 1, the minimum was observed during the premonsoon season and the maximum was observed during the summer season. At station 2, the minimum population density was observed during the monsoon season and the maximum was observed during the postmonsoon season.

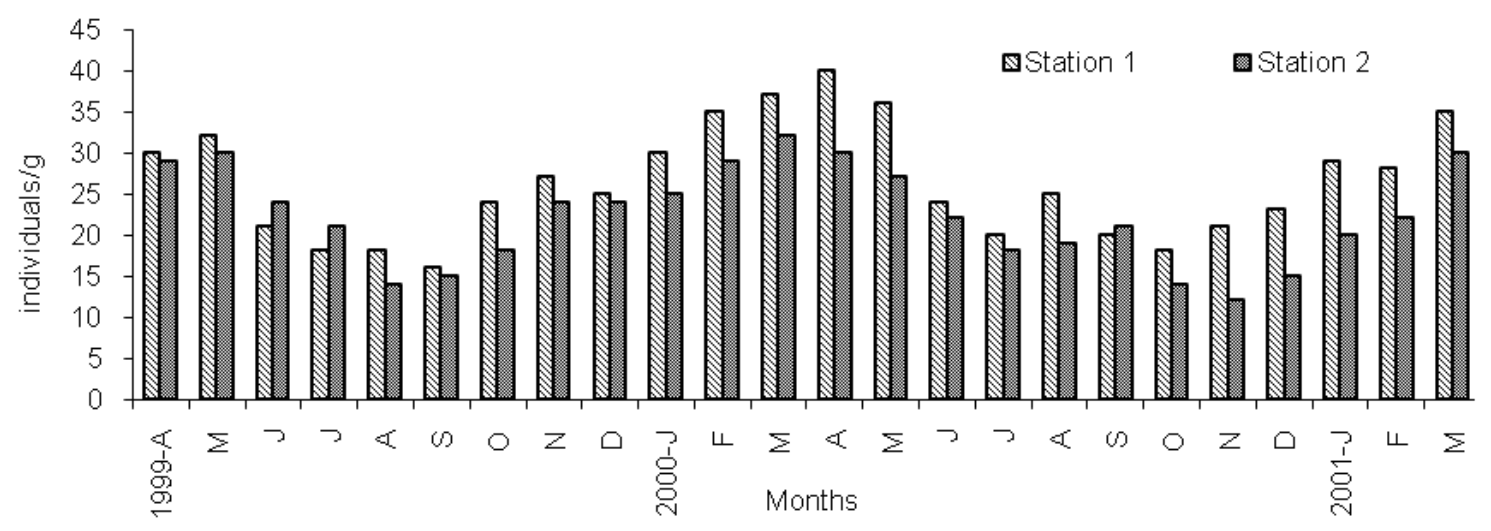

Figure 5. Population density of benthic cyanobacteria recorded at stations 1 and 2

\section{Fungi}

In the present study, a total of 35 species of fungi belonging to 20 genera (Table 3) were recorded from the water samples and 32 species of fungi belonging to 20 genera were recorded from the sediment samples collected from both stations.

Of the 35 species of fungi, 1 species belongs to 1 genus of Labyrinthulomycetes, 2 species belong to 1 genus of Oomycetes, 1 species belongs to 1 genus of Zygomycetes and 31 species belong to 17 genera of Deuteromycetes.

A total of 35 species belonging to 20 genera were identified from the water samples. Among the fungal colonies in water, Aspergillus niger contributed the maximum at station $1(15.7 \%)$ than at station $2(12.52 \%)$. A. terreus ranked second in its contribution at station $1(11.12 \%)$. Penicillium chrysogenum was the third dominant species $(8.43 \%)$ while non-sporulating black and white colonies contributed $6.50 \%$ at station 1 and $5.68 \%$ at station 2. 
Table 3. List of fungi recorded from the water and sediment samples of stations 1 and 2.

\begin{tabular}{|c|c|c|c|}
\hline S. No. & Title & Water & Sediments \\
\hline & \multicolumn{3}{|l|}{ LABYRINTHULOMYCETES } \\
\hline \multirow[t]{2}{*}{1.} & Labyrinthuloides minuta & + & + \\
\hline & \multicolumn{3}{|l|}{ OOMYCETES } \\
\hline 2. & Thraustochytrium aureum & + & - \\
\hline \multirow[t]{2}{*}{3.} & T. benthicola & + & + \\
\hline & \multicolumn{3}{|l|}{ ZYGOMYCETES } \\
\hline \multirow[t]{2}{*}{4.} & Mucor hiemalis & + & + \\
\hline & \multicolumn{3}{|l|}{ Deuteromycetes } \\
\hline 5. & Alternaria alternata & + & + \\
\hline 6. & A. longipes & + & + \\
\hline 7 & Aspergillus candidus & + & + \\
\hline 8 & A. flavus & + & - \\
\hline 9. & A. fumigatus & + & + \\
\hline 10 & A. glaucus & + & + \\
\hline 11 & A. niger & + & + \\
\hline 12 & A. sydowi & + & + \\
\hline 13 & A. nidulans & + & + \\
\hline 14 & A. terreus & + & + \\
\hline 15 & Cephalosporium humicola & + & + \\
\hline 16 & Cladosporium cladosporioides & + & + \\
\hline 17 & C. macrocarpum & + & + \\
\hline 18 & Fusarium equiseti & + & + \\
\hline 19 & F. oxysporum & + & + \\
\hline 20 & Penicillium chrysogenum & + & + \\
\hline 21 & P. citrinum & + & + \\
\hline 22 & P. funiculosum & + & + \\
\hline 23 & Scolecobasidium humicola & + & + \\
\hline 24 & Trichoderma koningii & + & + \\
\hline 25 & Lulworthia grandispora & + & + \\
\hline 26 & L. yorkensis & + & - \\
\hline 27 & Halosphaeria salina & + & + \\
\hline 28 & Halosarpheia marina & + & + \\
\hline 29 & Nimbospora octonae & + & + \\
\hline 30 & Ulkenia visurgensis & + & + \\
\hline 31 & Curvularia lunata & + & + \\
\hline 32 & Cladosporium herbarum & + & + \\
\hline 33 & Dendryphiella saline & + & + \\
\hline 34 & Trichoderma viride & + & + \\
\hline 35 & Phomamedi caginis & + & + \\
\hline 36 & Non sporulating black mycelium & + & + \\
\hline 37 & Non sporulating white mycelium & + & + \\
\hline
\end{tabular}


Fungi in water (Species composition and population density)

The fungal population density in water ranged from 3 to $20 \times 10^{1} \mathrm{CFU} \mathrm{ml} \mathrm{m}^{-1}$ at both the stations (Fig. 6). At station 1, the minimum was recorded during the summer season and the maximum in monsoon season. At station 2, the same trend was noticed.

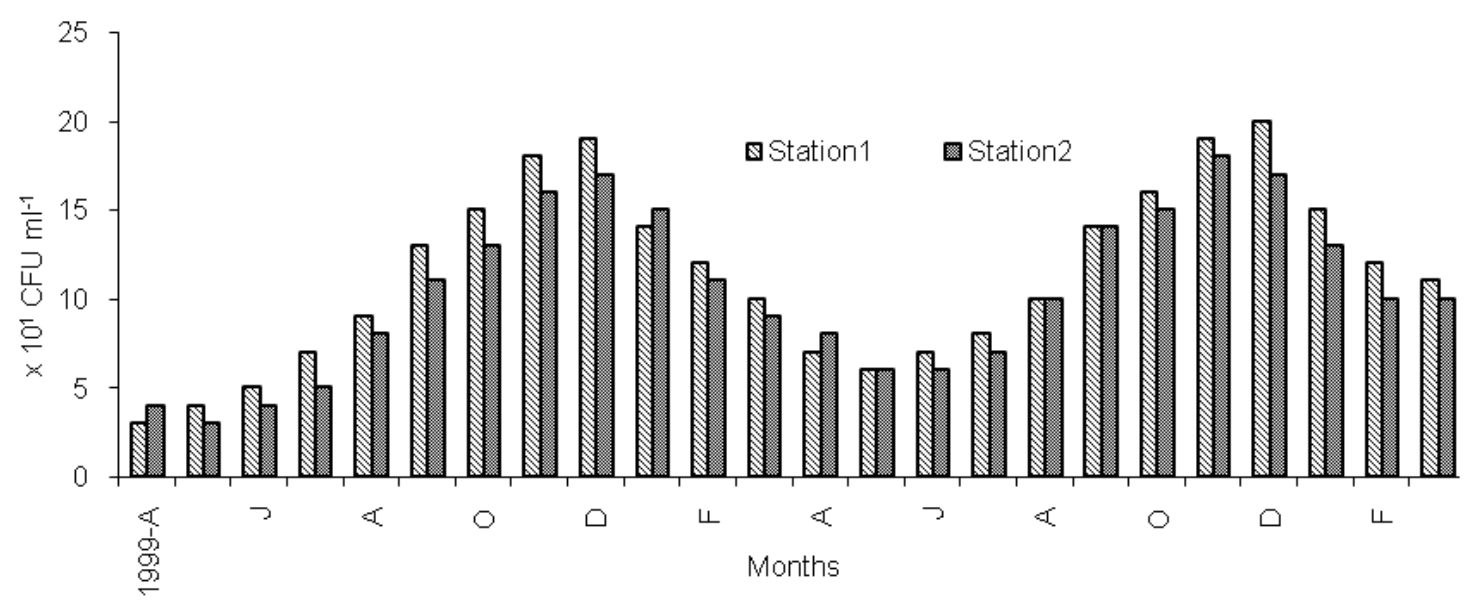

Figure 6. Population density of fungi recorded in water at stations 1 and 2

Fungi in sediments (Species composition and population density)

A total of 32 species belonging to 20 genera were identified from the sediment samples. Among the fungal colonies in sediments, A. niger contributed the maximum at station $1(18.26 \%)$ than at station $2(19.12 \%)$, followed by A. terreus i.e. $14.32 \%$ at station 1 and $16.18 \%$ at station 2. P. chrysogenum contributed $8.92 \%$ at station 1 and $9.14 \%$ at station 2 and non-sporulating black and white colonies contributed together $5.72 \%$ at station 1 and $4.78 \%$ at station 2 .

Aspergillus was the dominant genus recorded from both the stations. Thraustochytrium aureum, Aspergillus flavus and Lulworthia yorkensis were present only in the water samples at both the stations.

The fungal population density varied from 5 to $24 \times 10^{2} \mathrm{CFU} \mathrm{g}{ }^{-1}$ at both the stations (Fig. 7). At both the stations, the minimum was recorded during the postmonsoon and the maximum was recorded during the monsoon season.

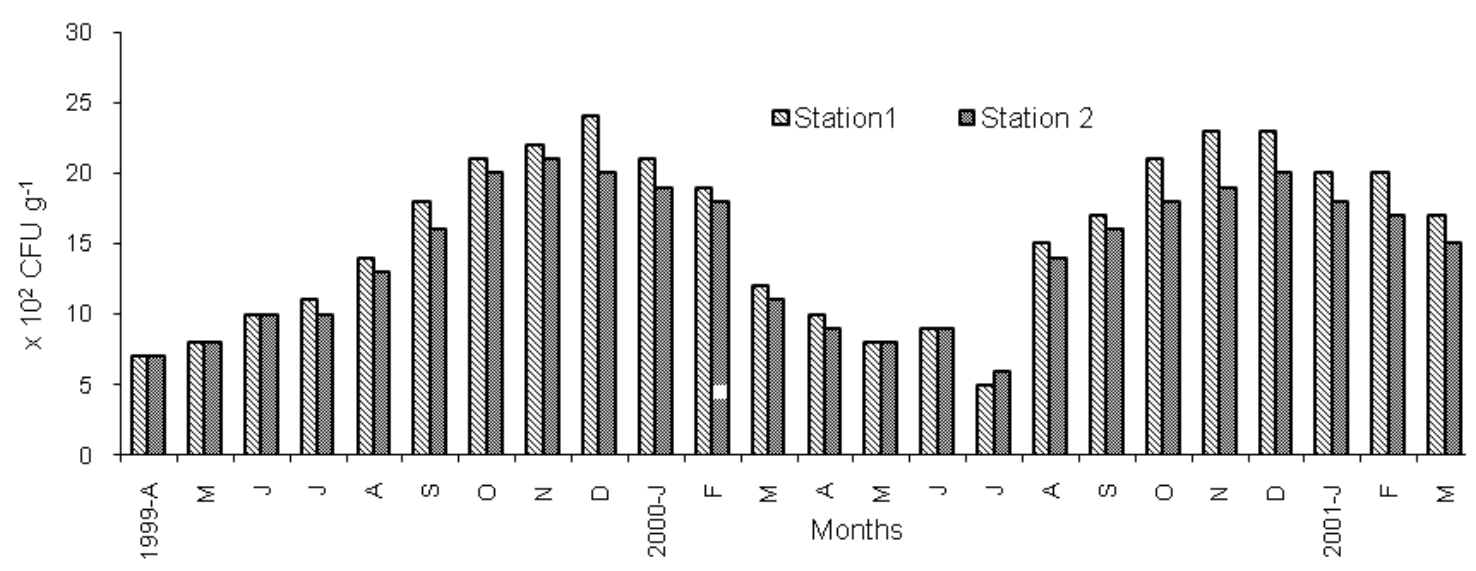

Figure 7. Population density in fungi recorded in sediments at stations 1 and 2 


\section{Discussion}

Bacteria are important in the coral reef environment in the recycling of nutrients and as a source of food to a variety of animal species (Disalvo, 1974; Sorokin, 1974). They also have an important trophic role to play in the reef environment, goverened by different physico-chemical and biotic factors. The coral reef environment supports the growth of bacteria and even the coral mucus which consists mainly of polysaccharides and proteins (Meikle et al., 1988) acts as a good growth substrate for bacteria (Fukami Kimio, 1994). In fact, some of the studies (Paul et al., 1986; Kannapiran, 1997) have revealed the presence of more bacterial population in coral mucus than in water. Hence, monitoring the THB population in the coral reef waters is considered to be one of the coral reef management practices.

It is in this line, the present study has revealed the presence of more THB population density (5.2 to $22.5 \times 10^{5} \mathrm{CFU} \mathrm{ml}^{-1}$ ) in the coral reef waters and in the sediments ( 7 to $24.2 \times 10^{7} \mathrm{CFU} \mathrm{g}^{-1}$ ) than in the surrounding coastal waters and sediments. Velankar (1955) has also recorded higher values of THB density in the sediments from the inshore waters of Mandapam. The THB population density recorded in the coral reef environment of the Gulf of Mannar during the present study is comparable to that of the other similar environment of Coconut Island (Sorokin, 1973) and Kaneole Bay (Disalvo, 1969).

Among the two stations studied, Manoli island recorded higher THB population density. This could be ascribed to the fact that seaweeds, seagrasses and mangroves are abundant here which produce a lot of detrital matter that gets drifted into the adjacent reef environment and favours the growth of THB.

Table 4. Multiple regression equation obtained for THB (water and sediments) vs. physicochemical parameters; cyanobacteria (planktonic and benthic)

\begin{tabular}{|c|c|c|}
\hline Type & Sample & Multiple regression equation \\
\hline \multirow[t]{2}{*}{ THB } & Water & $\begin{array}{l}Y=-85.836-.161 \mathrm{var} 1+.00708 \mathrm{var} 2-.658 \mathrm{var} 3+1.189 \mathrm{var} 4+1.145 \mathrm{var} 5- \\
.411 \mathrm{var} 6+.467 \mathrm{var} 7+.203 \mathrm{var} 8+.424 \mathrm{var} 9-7.249 \mathrm{var} 10+.208 \mathrm{var} 11 \\
+2.393 \mathrm{var} 12-.445 \mathrm{var} 13+2.428 \mathrm{var} 14-.0206 \operatorname{var} 15+.00455 \operatorname{var} 16\end{array}$ \\
\hline & Sediments & $\begin{array}{l}Y=-79.995-.300 \mathrm{var} 1+.00282 \mathrm{var} 2-.442 \mathrm{var} 3+.923 \mathrm{var} 4+10.076 \mathrm{var} 5- \\
.135 \mathrm{var} 6+.322 \mathrm{var} 7+.153 \mathrm{var} 8+1.242 \mathrm{var} 9- \\
7.929 \mathrm{var} 10+.240 \mathrm{var} 11+1.882 \operatorname{var} 12-.333 \mathrm{var} 13+2.285 \mathrm{var} 14- \\
.0149 \mathrm{var} 15+.00229 \mathrm{var} 16\end{array}$ \\
\hline \multirow[t]{2}{*}{ Cyanobacteria } & Planktonic & $\begin{array}{l}Y=-1029.565-8.282 \operatorname{var} 1-.06067 \operatorname{var} 2- \\
8.143 \operatorname{var} 3+19.015 \operatorname{var} 4+80.620 \operatorname{var} 5+11.310 v a r 6-10.844 \operatorname{var} 7+ \\
2.699 \operatorname{var} 8+16.785 \operatorname{var} 9-156.361 \operatorname{var} 10+11.042 \operatorname{var} 11+83.212 \operatorname{var} 12- \\
21.982 \operatorname{var} 13+15.028 \operatorname{var} 14-.337 \operatorname{var} 15-.009878 \operatorname{var} 16\end{array}$ \\
\hline & Benthic & $\begin{array}{l}Y=+11.913-1.485 \operatorname{var} 1+.01692 \mathrm{var} 2-1.086 \mathrm{var} 3+1.360 \mathrm{var} 4- \\
6.714 \mathrm{var} 5+2.007 \mathrm{var} 6+1.174 \mathrm{var} 7-.02623 \mathrm{var} 8+.487 \mathrm{var} 9- \\
12.461 \mathrm{var} 10+.359 \operatorname{var} 11+2.095 \operatorname{var} 12-.470 \mathrm{var} 13+.989 \mathrm{var} 14- \\
.02071 \mathrm{var} 15+.01171 \mathrm{var} 16\end{array}$ \\
\hline \multirow[t]{2}{*}{ Fungi } & Water & 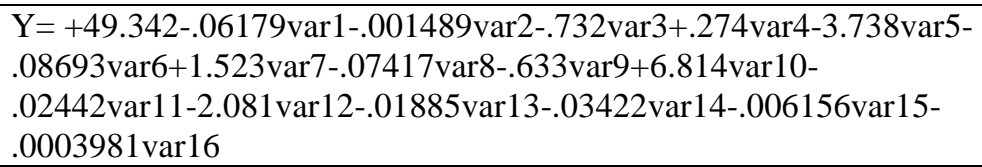 \\
\hline & Sediments & $\begin{array}{l}Y=+115.390-.196 \operatorname{var} 1-.003354 \mathrm{var} 2-.636 \mathrm{var} 3-.678 \mathrm{var} 4- \\
15.853 \mathrm{var} 5+1.226 \mathrm{var} 6+2.522 \mathrm{var} 7+.06166 \mathrm{var} 8- \\
1.359 \mathrm{var} 9+11.331 \mathrm{var} 10+.03012 \mathrm{var} 11-2.934 \mathrm{var} 12+.199 \mathrm{var} 13- \\
1.252 \mathrm{var} 14+001687 \mathrm{var} 15+.007805 \mathrm{var} 16\end{array}$ \\
\hline
\end{tabular}


In the present study, higher THB population densities were noticed during the monsoon and postmonsoon seasons at both the stations in water and sediments. This could be attributed to the land runoff, which is expected to bring more amount of organic and inorganic nutrients to the reef environment, a situation favourable for the growth of THB.

With regard to the environmental parameters, changes in salinity and temperature could influence the distribution of bacteria (Morita, 1974; Mohan Kumar et al., 1979). This could be observed in the present study also. Higher THB populations were recorded during the monsoon season when the salinity was lower due to the freshwater inflow. The lower salinity and the excess nutrients would have favoured the growth of the THB populations. Carlucci (1974) observed that the availability of nutrients particularly phosphate and total nitrogen as yet another important factor governing the distribution of marine bacteria. In the present study, during the monsoon season, higher values of phosphate ( $4.6 \mu \mathrm{M}$ at stations 1 and 2$)$ and total nitrogen $(44.2 \mu \mathrm{M}$ at station 1 and $39.0 \mu \mathrm{M}$ at station 2) were noticed, coinciding with higher bacterial population density.

Table 5. Multiple regression equation obtained for THB (water and sediments) vs. physicochemical parameters; cyanobacteria (planktonic and benthic) vs. physico-chemical parameters and fungi (water and sediments) vs

\begin{tabular}{|c|c|c|}
\hline Type & Sample & $\begin{array}{l}\text { Multiple regression equation } \\
\end{array}$ \\
\hline \multirow[t]{2}{*}{ THB } & Water & $\begin{array}{l}Y=-95.321-.03513 \operatorname{var} 1+.009261 \operatorname{var} 2- \\
.461 \operatorname{var} 3+1.011 \operatorname{var} 4+11.889 \operatorname{var} 5-.386 \operatorname{var} 6+.228 \operatorname{var} 7 \\
+.187 \operatorname{var} 8+.358 \operatorname{var} 9-7.115 \operatorname{var} 10+.317 \operatorname{var} 11+2.758 \operatorname{var} 12- \\
.392 \operatorname{var} 13+2.110 \operatorname{var} 14-.01759 \operatorname{var} 15+.004033 \operatorname{var} 16\end{array}$ \\
\hline & Sediments & $\begin{array}{l}Y=-91.407-.04594 \operatorname{var} 1+.01053 \operatorname{var} 2-.279 \operatorname{var} 3+.824 \operatorname{var} 4+12.205 \mathrm{var} 5- \\
.509 \mathrm{var} 6+.667 \mathrm{var} 7+.118 \mathrm{var} 8+.294 \mathrm{var} 9-7.300 \mathrm{var} 10+.08174 \mathrm{var} 11- \\
.905 \mathrm{var} 12+.109 \mathrm{var} 13+2.447 \mathrm{var} 14-.01343 \operatorname{var} 15+.003159 \mathrm{var} 16\end{array}$ \\
\hline \multirow[t]{2}{*}{ yanobacteria } & Planktonic & $\begin{array}{l}Y=-786.883-7.025 \mathrm{var} 1-.01251 \mathrm{var} 2- \\
7.522 \mathrm{var} 3+15.060 \mathrm{var} 4+88.720 \mathrm{var} 5+3.416 \mathrm{var} 6- \\
7.774 \mathrm{var} 7+2.565 \mathrm{var} 8+13.096 \mathrm{var} 9- \\
144.812 \mathrm{var} 10+9.187 \mathrm{var} 11+88.717 \mathrm{var} 12-21.092 \mathrm{var} 13+14.528 \mathrm{var} 14- \\
.350 \mathrm{var} 15+.003440 \mathrm{var} 16\end{array}$ \\
\hline & Benthic & $\begin{array}{l}Y=+18.590-.830 \mathrm{var} 1+.02354 \mathrm{var} 2-.447 \mathrm{var} 3+1.010 \mathrm{var} 4+4.729 \mathrm{var} 5- \\
.310 \mathrm{var6}-1.604 \mathrm{var} 7+.114 \mathrm{var} 8-1.201 \mathrm{var} 9- \\
12.078 \mathrm{var} 10+.188 \mathrm{var} 11+2.692 \mathrm{var} 12-1.444 \mathrm{var} 13+2.426 \mathrm{var} 14- \\
.04572 \mathrm{var} 15-.001074 \mathrm{var} 16\end{array}$ \\
\hline \multirow{2}{*}{ Fungi } & Water & $\begin{array}{l}Y=+69.056+.115 \operatorname{var} 1+.008787 \text { var2-.648var3-.103var4-4.370var5- } \\
.219 \mathrm{var} 6+1.239 \mathrm{var} 7-.08866 \mathrm{var} 8-2.466 \mathrm{var} 9+9.678 \mathrm{var} 10-.636 \mathrm{var} 11- \\
10.308 \mathrm{var} 12+1.282 \operatorname{var} 13+.491 \mathrm{var} 14+.003607 \operatorname{var} 15+.0007551 \mathrm{var} 16\end{array}$ \\
\hline & Sediments & $\begin{array}{l}Y=+92.960-.172 \operatorname{var} 1+.002077 \mathrm{var} 2-.604 \mathrm{var} 3-.305 \mathrm{var} 4- \\
12.018 \mathrm{var} 5+.774 \mathrm{var} 6+1.949 \mathrm{var} 7+.06151 \mathrm{var} 8- \\
.796 \mathrm{var} 9+7.837 \mathrm{var} 10+.07119 \mathrm{var} 11-2.000 \mathrm{var} 12+.148 \mathrm{var} 13-1.074 \mathrm{var} 14- \\
.0004744 \mathrm{var} 15+.005478 \mathrm{var} 16\end{array}$ \\
\hline
\end{tabular}

The above facts are substantiated by the regression analysis performed among the different variables such as rainfall, surface water temperature, $\mathrm{pH}$, dissolved oxygen, particulate organic carbon, total phosphorus, total nitrogen, nitrite, reactive silicate and magnesium which showed influence on the THB populations in water and sediments of both the stations (Tables 4 and 5). 
In the present study, Bacillus, Micrococcus, Arthrobacteium, Corynebacterium, Pseudomonas, Vibrio, Aeromonas, Flavobacterium and Enterobacter were recorded from both the stations. Among them, Bacillus was found to be the dominant genus in the gram positive group and in the gram negative group, Pseudomonas was the dominant genus. Vibrio was the second dominant genus in the gram negative group. In general, the gram negative bacteria recorded a higher proportion than the gram positive bacteria. This lends support to the observations of Kannapiran (1997) and Velankar (1955).

In the present study, a total of 24 species of planktonic cyanobacteria belonging to 15 genera and 5 families were recorded. The detailed study revealed that 6 genera comprising 8 species are assignable to the family Chroococcaceae, 5 genera comprising 11 species to Oscillatoriaceae, 2 genera comprising 2 species to Nostocaceae, 1 genus with 2 species to Scytonemataceae and 1 genus with 1 species to Rivulariaceae. Among these, 4 species (Aphanocapsa montana, Aphanothece clathrata, Synechocystis pevalekii and $S$. aquatilis) belonging to 3 genera of the family Chroococcaceae have been reported as fresh water forms by Desikachary (1959).

A total of 11 species of benthic cyanobacteria belonging to 8 genera were also recorded in the present study. Among these, 4 species of 3 genera belong to the family Chroococcaceae, 5 species of 3 genera belong to Oscillatoriaceae, 1 species of 1 genus belongs to Nostocaceae and 1 species of one genus belongs to Rivulariaceae. Out of these, 3 species (Chroococcus minutus, C. minor and Aphanocapsa montana) belonging to 2 genera have been reported as freshwater forms by Desikachary (1959). This could be due to the remarkable adaptability of cyanobacteria to any environment (Desikachary, 1959; Fogg, 1973; Carr and Whitton, 1982; Hof and Fremy, 1993).

Among the different cyanobacteria recorded in the present study, Phormidium tenue was the most dominant species and the families Oscillatoriaceae and Chroococcaceae were predominant in the present study, thus conforming to the observations of Thajuddin and Subramaniyan (1992) in the Bay of Bengal, adjoining the south east coast of India.

During the present study, higher nutrient contents (especially nitrogen) were noticed, which could be correlated with the maximal diversity and density of the cyanobacteria. Regression analysis (Tables 4 and 5) has also indicated that surface water temperature, $\mathrm{pH}$, salinity, particulate organic carbon, total phosphorus, total nitrogen, nitrate and reactive silicate have influence on the planktonic cyanobacterial populations at station 1 , in addition to magnesium which has influence on these organisms at station 2 . In the case of benthic cyanobacteria, rainfall, surface water temperature, salinity, dissolved oxygen, total phosphorus, total nitrogen, nitrite, reactive silicate and magnesium have influence on these organisms.

In the present study, a total of 35 species of fungi belonging to 20 genera representing the families Labyrinthulomycetes, Oomycetes, Zygomycetes and Deuteromycetes were isolated. Among them, the deuteromycetous fungi formed the bulk of the mycoflora of water and sediment samples at both the stations. Predominance of deuteromycetes observed in the present study is in conformity with the earlier observations of Upadhyay et al. (1978), Venkatesan (1981), Dasarathy (1983) and Nadimuthu (1998) in different parts of the southeast coast of India.

Aspergillus with 8 species (Aspergillus candidus, A. flavus, A. fumigatus, A. glaucus, A. niger, A. sydowi, A. nidulans and A. terreus) was found to be the most dominant genus in the water and sediment samples at both the stations. Rai and Chowdhery 
(1978) have also noted the Aspergillus dominance as the characteristic feature of soils of warmer regions.

During the present investigation, higher fungal population density in water at station $1\left(20 \times 10^{1} \mathrm{CFU} \mathrm{ml}^{-1}\right)$ and at station $2\left(18 \times 10^{1} \mathrm{CFU} \mathrm{m}^{-1}\right)$ and in sediments at station 1 $\left(24 \times 10^{2} \mathrm{CFU} \mathrm{g^{-1 }}\right)$ and at station $2\left(21 \times 10^{2} \mathrm{CFU} \mathrm{\textrm {g } ^ { - 1 }}\right)$ was recorded during the

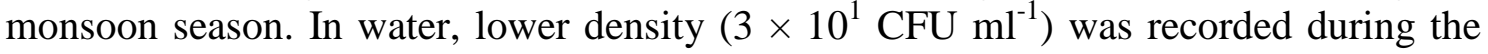
summer season at both the stations. In sediments, lower density was recorded at station $1\left(5 \times 10^{2} \mathrm{CFU} \mathrm{g}{ }^{-1}\right)$ and station $2\left(6 \times 10^{2} \mathrm{CFU} \mathrm{g}{ }^{-1}\right)$ during the postmonsoon season. Copious amount of rainfall during the monsoon season might have provided the necessary nutrients and substratum for fungi to thrive well and multiply thereby leading to their higher counts during this season (Untawale and Parulekar, 1976; Matondker et al., 1980; Muniyandi, 1985). The lower population density of fungi recorded during the summer season could be ascribed to the toxicity caused by higher concentration of chloride ions (Swart, 1958).

From the present study, it is understood that the THB, cyanobacteria and fungi have distinct spatio-temporal variations in their qualitative and quantitative distributions at both the stations. Under the normal conditions, these microbes can co-exist with other organisms including corals in the marine environment without harming them (Andrew Baird, 2000). But, the environmental stresses can make them virulent and cause disease to their associated flora and fauna. The influence of different environmental parameters on the microflora (THB, cyanobacteria and fungi) could be understood in the present study through the multiple regression analysis (Tables 4 and 5). This would suggest that a continuous monitoring of the microflora and the physico-chemical parameters in the coral reef environment of the Gulf of Mannar is therefore essential, as a measure of coral reef management practice, since there are abundant populations of microflora in the reef environment as well as coral microbial diseases.

Acknowledgements. The Director, CAS in Marine Biology and the authorities of Annamalai University is thanked for providing facilities and the Ministry of Environment and Forests for providing financial support. Authors thank Mr. N. Rajendra Prasad, Executive Director, People's Action for Development (PAD), Vembar for helping to publish this manuscript.

\section{REFERENCES}

[1] Ainsworth, G.C., Sparrow, F.K., Sussman, A.S. (1973a): The fungi, An advanced treatise. A taxonomic review with keys. Ascomycets and fungi imperfecti. - Vol. IV A, Academic Press New York, 621 pp.

[2] Ainsworth, G.C., Sparrow, F.K., Sussman, A.S. (1973b): The fungi, An advanced treatise. A taxonomic review with keys. II. Basidiomycetes and lower fungi. - Vol. IV B, Academic Press New York, 504 pp.

[3] Anand, N. (1989): Hanbook of blue-green algae (of rice field of south India). - Bishen Singh Mahendra Pal Singh, Dehra Dun 80 pp.

[4] Baird, A. (2000): Microbial menance. Exploring reef science. - CRC reef research center $1-2$.

[5] Booth, C. (1971): The genus Fusarium Commonwealth Mycological Institute, Kew Survey. - England 237pp.

[6] Buchanan, R.E., Gibbons, N.E. (eds.) (1975): Bergey's manual of determinative bacteriology. $8^{\text {th }}$ ed. - The Williams and Wilkins, Baltimore $1268 \mathrm{pp}$. 
[7] Carlucci, A.P. (1974): Nutrients and microbial response to nutrients in seawater. - In: Effect of the ocean environment of microbial activities. Univ. Park Press, Baltimore, M.D., USA, 245-248.

[8] Carr, N.G., Whitton, B.A. (1982): The Biology of cyanobacteria. - Blackwells Scientific Publications $688 \mathrm{pp}$.

[9] Dasarathy, G. (1983): Sediment mycoflora of Porto Novo marine environment. - M.Phil. Thesis, Annamalai University, 69 pp.

[10] Desikachary, T.V. (1959): Cyanophyta, a monograph - I.C.A.R. Pub., New Delhi, 686 pp.

[11] DiSalvo, I.H. (1974): Soluble phosphorus and amino nitrogen released in seawater during recoveries of coral reef regenerative sediments. - Pro. $2^{\text {nd }}$ Inter. Symp. Coral Reefs 1: 2-7.

[12] DiSalvo, L.H. (1969): Regeneration function and microbial ecology of coral reefs. Doctoral thesis, Univ. of North Carolina, U.S.A.

[13] Ducklow, H.W. (1990): The biomass, production and fate of bacteria in coral reefs. - In: Dubinsky, Z. (ed.), Ecosystems of the world, Vol. 25, Coral reefs, 265-290. Elsevier Science Publishing, NewYork, 550p.

[14] Ellis, M.B. (1976): More Dematiaceous Hyphomycetes. - Common wealth mycological Institute, Kew, Surrey, England, 507 pp.

[15] Fogg, G.E. (1973): Physiology and Ecology of Marine blue-green algae. - In: Carr, N.G. and Whitton, B.A. (ed.). "The Biology of blue-green algae". Blackwell Scientific Publication, $676 \mathrm{pp}$.

[16] Fukami, K. (1994): Bacterial growth in coral reef seawater supplemented with coral mucus and ammonium. - Bull. Mar. Sci. and Fisheries 14: 35-36.

[17] Hagstrom, A., Azam, F., Anderson, A., Wikner, J., Rassoulazadegan, R. (1988): Microbial loop in an oligotrophic pelagic marine ecosystem: Possible roles of Cyanobacteria and nanoflagellates in the organic fluxes. - Mar. Ecol. Prog. Ser. 49: 171178.

[18] Hof, T., Fremy, P. (1993): On myxophyceae living in strong brines. - Rev. Trav. Bot. Neerland 30: 140-162.

[19] Hoppe, H.G., Scrhramm, W., Bacolod, P. (1988): Spatial and temporal distribution of pelagic microorganisms and their proteolytic activity over a partly destroyed coral reef. Mar. Ecol. Prog. Ser. 44: 95-102.

[20] Hoppe, H.G., Gocke, K. (1993): The influence of global climate and hydrography on microbial activity in the ocean, results of N-S Atlantic transect. - Proc. Inter. Symp. Environ. Microbiol, Korea: 93-110.

[21] Hum, H. J., Wicks, S.R. (1980): Introduction and guide to the marine blue-green algae. John Wiley \& Sons, New York, 194.

[22] Kannapiran, E. (1997): Heterotrophic, phosphatase producing and phosphate solubilizing bacteria of the coral reef environment of the Gulf of Mannar Biosphere Reserve (southeast coast of India): An inventory. - Ph.D., thesis, Annamalai University, 103.

[23] Kohlmeyer, J., Kohlmeyer, E. (1979): Marine Mycology. The Higher fungi. - Academic Press, New York, 690.

[24] Krieg, N.R. (1984): Bergey's manual of d systematic bacteriology. - The Williams and Wilkins, Baltimore I, 964.

[25] Matondkar, S.G.P., Mahtani, S., Mavinkurve, S. (1980): The fungal flora of the mangrove swamps of Goa. - Mahasagar 13(3): 281-283.

[26] Meikle, P., Richards, G.N., Yellowless, D. (1988): Structural investigation on the mucus from six species of corals. - Mar. Biol. 99: 187-193.

[27] Mohankumar, K.C., Manohar, L., Hariharan, V., Reddy, M.P.M. (1979): Effect of temperature and salinity on the microbial population in the Arabian sea coastal waters at Mangalore (India). - Mahasagar 12(1): 35-39. 
[28] Morita, R.Y. (1974): Temperature effects on marine microorganisms. - In: Effect of the ocean environment on microbial activities. In: R.R. Colwell and R.Y. Morita (Eds.), University Park Press, Baltimore: 75-79.

[29] Muniyandi, K. (1985): Studies on mangrove of Pitchavaram (southeast coast of India). Ph.D. Thesis, Annamalai University, 215.

[30] Nadimuthu, N. (1998): Studies on the fungi of the coral reef environment of the Gulf of Mannar Biosphere Reserve, India. - Ph.D. Thesis, Annamalai University, 117.

[31] Paul, J.H., De Klaun, M.F., Jeffrey, W.H. (1986): Elevated levels of microbial activity in the coral surface microlayer. - Mar. Ecol. Prog. Ser. 33: 29-40.

[32] Prabu, S.K., Subramanian, B., Mahadevan, A. (1991): Mycoflora of sediment and waters of the Madras coast, Bay of Bengal. - Indian J. Mar. Sci. 20: 226-228.

[33] Rai, J.N., Chowdhery, H.J. (1978): Microfungi from mangrove swamps of West Bengal, India. - Geophytology 8(1): 103-110.

[34] Rohrmann, S., Molitoris, H.P. (1992): Screening for wood degrading enzymes in marine fungi. - Can. J. Bot. 70: 2106-2110.

[35] Sargent, M.C., Austin, T.S. (1949): Organic productivity of an atoll. Trans.Amer.Geophys. Union 30: 245-249.

[36] Sneath, P.H.A. (1986): Bergey's manual of systematic bacteriology, Vol. 2. - The Williams and Wilkins, Baltimore, 965-1599.

[37] Sorokin, Y.I. (1973): Tropical role of bacteria in the ecosystem of the coral reef. Nature, London 242: 415-417.

[38] Sorokin, Y.I. (1974): Bacteria as a component of the coral reef community. - Proc. Second Int. Coral Reef Symp. Brisbane 1: 3-10.

[39] Swart, H.J. (1958): An investigation of the mycoflora in the soil of some mangrove swamps. - Acta Bot. Neerl. 7: 741-768.

[40] Thajuddin, N., Subramanian, G. (1992): Survey of cyanobacterial flora of the southern east coast of India. - Bot. Mar. 35: 305-314.

[41] Untawale, A.G., Parulekar, A.H. (1976): Some observations on the ecology of an estuarine mangrove of Goa. - Mahasagar 9(1-2): 57-62.

[42] Upadhyay, R.S., Singh, D.B., Bharat Rai, (1978): Ecology of microfungi in a tropical coastal sand belt. - Indian J. mar. Sci. 7: 187-190.

[43] Velankar, N.K. (1955): Bacteria in the inshore environment at Mandapam. - Indian J. Fish. 2: 96-112.

[44] Venkatesan, T. (1981): Studies on mycoflora of Pitchavaram mangrove near Porto Novo (South India). - Ph.D. Thesis, Annamalai University, 236 pp. 